\title{
Numerical Modelling of Waterlogging Problem in New Urbanized Communities in Al-Qairawan area, Kuwait
}

\author{
Mohamed I. GAD ${ }^{1}$, Ahmed E. Al-Nimr ${ }^{2}$, and Hamoud N. Alalati ${ }^{3}$ \\ ${ }^{I}$ Prof and Head of Hydrology Division, Desert Research Center, Cairo, Egypt. \\ ${ }^{2}$ Prof of Soil Mechanics, Faculty of Eng., Mansourah Univ., Mansourah, Egypt. \\ ${ }^{3}$ PhD Student, Faculty of Eng., Mansourah Univ., Mansourah, Egypt.
}

\begin{abstract}
Expanding the urbanization of new communities within the limited low flat desert surfaces of Al-Qairawan area, Kuwait has started to face the continuous growth of population. The traditional urbanized logged areas affect urbanization of these flat desert surfaces as a result of the difference in the topographic level, inadequate drainage system and the existence of inland Sabkhas beside shallow-depth clay lenses beneath these sites. Moreover, the soil water depths vary from few centimeters below ground surface to $5.5 \mathrm{~m}$ and the soil-water moves generally from the southwest to the northeast towards the Arabian Gulf. The present paper threw light on a trial to mitigate the waterlogging problem due to the bad use of water resources in Gardening-irrigation activities in the relatively high-land areas of the present traditional urbanized communities in Al-Qairawan area applying mathematical modeling. The groundwater flow model, Visual MODFLOW v.3, was used to test the reliability of the proposed solution for mitigation and its limitation. Three proposed scenarios for mitigation of waterlogging problem were checked. Decreasing the soil water level using wall sheet system was proposed as a first scenario. The second scenario proposed suitable dewatering system while the third one assumed the construction of transverse open drainage system in the southern boundary of the study area. The results showed that the third scenario was the best solution since it reflected both the lowest soil water level $(2.72 \mathrm{~m})$ and least cost economically (146250 Kuwait-Dinar). Accordingly, the solution concerning soil water rise control in the study area through applying the construction of transverse open drain in the southern boundary of the study water logged area is highly recommended.
\end{abstract}

Keywords: Hydrogeology, Water logging problem, Visual MODFLOW, Cost benefit ratio, Kuwait

\section{1-INTRODUCTION}

Waterlogging problem is age-old nemesis of both urbanized areas and irrigated agriculture, and it continues to plague urbanization development and irrigated regions around the world. In fact, about $25 \%$ of the world's irrigated land is affected by waterlogging and salinity due to saline high water tables (Tanji 1990, Ghassemi et al. 1995). It has been estimated that 2.5 to 5 million acres of mostly prime agricultural land are becoming severely damaged through irrigationinduced salinization each year (Umali 1993, Kovda 1983). Ghassemi et al. (1995) estimated that worldwide productivity loss is valued at about $\$ 10$ billion per year. Also, concern is strong regarding possible long-term damage to the environment from downward percolating waters, return flows to rivers, and disposal of saline drainage water.

In addition, the special adherence to the water logging situation in the metropolitan cites on the world, there are so many examples and case studies has been done like in Bangladesh, the Teknaf urban area are affected by internal rain fed flood, this project also provide some recommendation to get rid of this stations (Anisha et al., 2014). Another case study has been made in Dhaka, the capital of Bangladesh have also faced the problem of water logging due to poor urban drainage problem which impact on the population by environmentally (water pollution, Water borne diseases etc) and socially (disruption of traffic , disruption of normal life, etc) (Alom et al., 2014). In India a case study has been drawn over four metropolitan cities like Kolkata, Chennai, Delhi and Mumbai, about the urban flooding from the period of 1988 to 2007 (Roy and Dhali, 2016). They have identified the reasons and showed how the people are impacted in this situation and provide some recommendation (Singh et al., 2013).In Egypt, the results of mathematical modeling studies concluded that the dewatering system is the most prefer method for water logging problem (Attia, 1989, Gad, 2000, Sakr, et. Al., 2002, El-Rayes and Geriesh, 2002, Gad, 2004, ElHefnawy, et al., 2006, Saafan, et al. 2009, El Sheikh et. Al., 2013, and Kaiser et al., 2013).

In Saudi Arabia, El-Nimr 1991, 1994 \& 1995 studied the impact of groundwater rise on the infrastructures in Al-Riyadh applying mathematical modeling. In Kuwait, Al-Rashed, et al. (1998) 
mentioned that the groundwater level rises by about $3 \mathrm{~m}$ in urban areas which threatening the integrity of several buildings and roads. So, the best solution of water logging problem in Al-Qairawan Urbanizes Logged Area (AQULA), Kuwait can be formulated in different ways but the basic approach in this work is to use simulation models to identify strategies that come close to maximizing economic net benefits over AQULA (Gates and Grismer 1989, Gates, Wets, and Grismer 1989, Grismer and Gates 1991, Garcia, Manguerra and Gates 1995).

\section{1-Site Description and Climate}

AQULA is located west of Kuwait city by about $30 \mathrm{Km}$ and south of Arabian Gulf by about one $\mathrm{Km}$ (Fig.1). It is limited between latitudes 3240290 and 3253453 due North and longitudes 758015 and 779143 due East with an area of about $278 \mathrm{Km} 2$. A strip of about $3 \mathrm{Km}$ wide separates AQULA from Arabian Gulf. From west, Al-Jahra table land area bounds AQULA while from the north, Arabian Gulf forms the northern boundary of AQULA. The climate of Kuwait can be divided into two main seasons, hot with temperature ranges between $46{ }^{\circ} \mathrm{C}$ and $50{ }^{\circ} \mathrm{C}$ and from $20{ }^{\circ} \mathrm{C}$ to Zero ${ }^{\circ} \mathrm{C}$ during winter months (November through March). The mean annual precipitation was about $115 \mathrm{~mm}$, and the monthly average $9.6 \mathrm{~mm}$ while the mean daily Pan-A evaporation rate recorded varied from $4.7 \mathrm{~mm}$ in January to $31 \mathrm{~mm}$ in July, with an average mean daily rate of $16.6 \mathrm{~mm}$ (Safar 1985).

\subsection{Geomorphological Setting}

AQULA is classified into four geomorphological units, Coastal hills, Sand dune fields, Flat desert surfaces and Wadis (Al-Sarawi 1982, El-Baz \& Al-Sarawi 1996 \& 2000, AlSulaimi and Al-Ruwaih 2004) (Fig.2). The coastal hills occupy the northern and southern parts of Kuwait, which are a hard, flat desert with shallow depressions and small conical hills with an average height of about $40 \mathrm{~m}$. The sand dune fields and dust accumulation pattern occupy an area covering 350$500 \mathrm{~km}^{2}$.

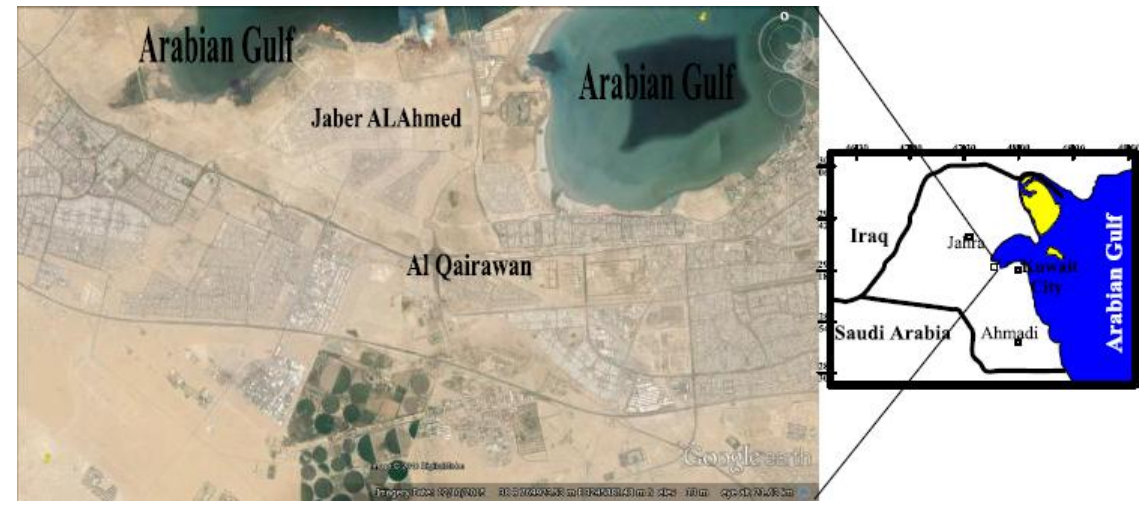

Fig. 1: Location map of the study area

The highest rates of sand transport occur across this region. Flat desert surfaces cover most of the lowland of southern Kuwait, and are controlled by wind action. The surface topography reflects a long period of deflation. Wadi Al-Batin is a large valley that forms a natural boundary between the State of Kuwait and the Republic of Iraq and varies in width from 7 to $10 \mathrm{~km}$ with relief up to $57 \mathrm{~m}$. The wadi extends over a distance of $180 \mathrm{~km}$ in Kuwait.

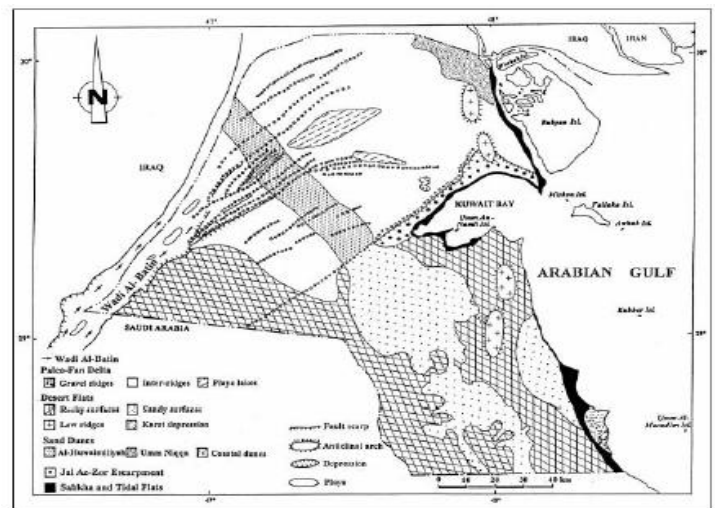

Fig. 2: Geomorphic provinces of Kuwait (after El-Baz \& Al-Sarawi 2000) 


\subsection{Geological Setting}

The details of the geology of rock units of AQULA have been presented by Owen and Nasr (1958), Milton (1967), Fuchs et al. (1968), Burdon and Al-Sharhan (1968), Omar et al. (1981), Clarke (1988), Al-Sulaimi (1988), Amer et al. (1989), AlSulaimi and Pitty (1995), Mukhopadhyay et al. (1996), Al-Sulaimi and Mukhopadhyay (2000), AlSulaimi and Al-Ruwaih (2004) as well as the geologic maps and landsat images (El-Baz \& AlSarawi 2000) in addition to field investigation (Fig.3). Based on these studies, the main lithostratigraphic units forming the bedrock of Kuwait are unconsolidated to semi-consolidated clastic sediments of the Kuwait Group (postEocene Age), which unconformably overlies the dolomitic Dammam Formation of the Eocene Age. The surface of Kuwait is predominantly covered by Quaternary sediments which include Pleistocene gravel and sand of the upper member of the Dibdibba Formation and Holocene sediments including marine sand, coastal deposits, beach rocks, sabkha deposits, desert floor deposits, alluvium and aeolian sands.

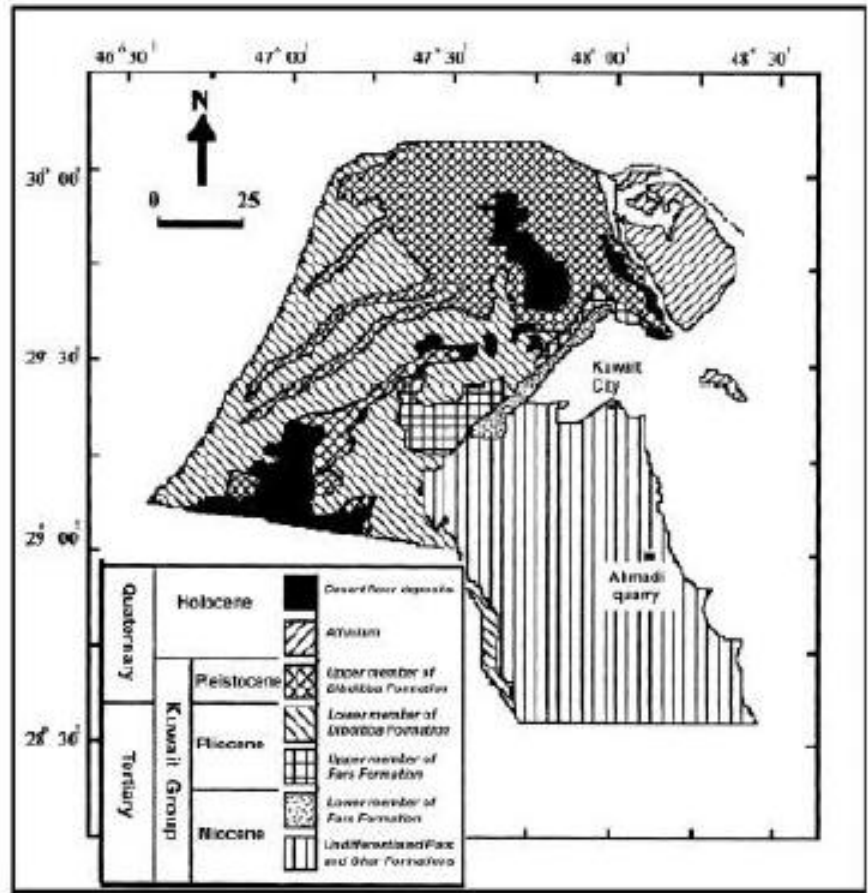

Fig. 3: Simplified surface geological map of Kuwait (after HGG 1981)

Structurally, Kuwait lies on the Arabian Shield, an area noted for its stability since the Cambrian period. The Shield tilts slightly to the northeast, giving rise to sedimentation of the Arabian Shelf, and consists of a sequence of laterally extensive, but thin limestones, marls, shales, sandstones and evaporites. Tertiary geological events in Kuwait influenced the present lithology, depth, thickness, and geometry of the major rock units in Kuwait (Fig.4).

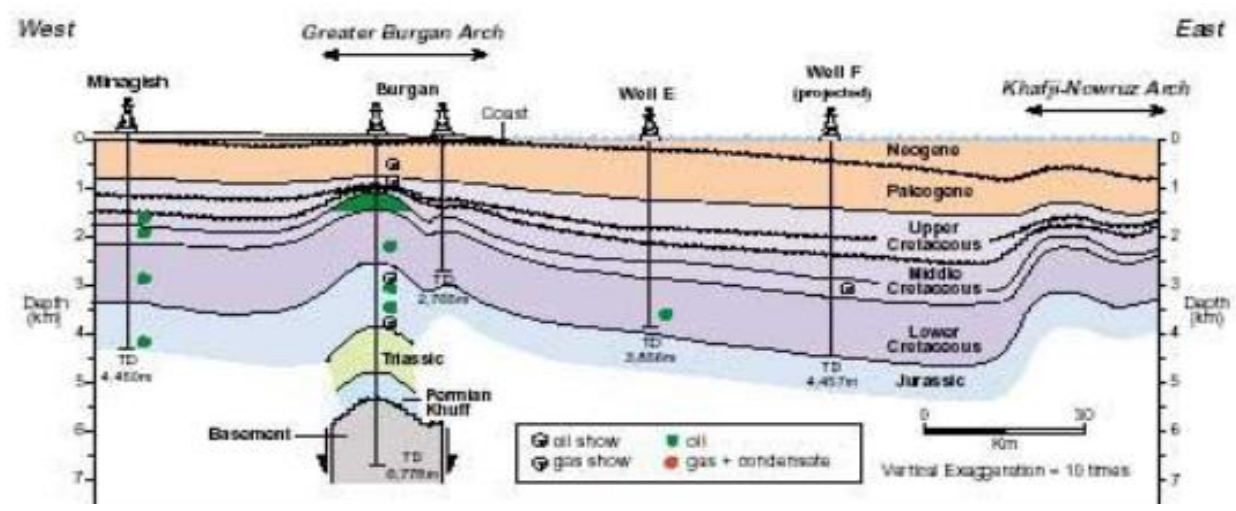

Fig.4: Geological cross section of Kuwait off shore and coastal area. 
Pre-Neogene (pre-Miocene) movement shaped the configuration of the Paleocene - Eocene (Paleogene) rocks of the Hasa Group and determined the geometry of the pre- Neogene unconformity surface, on which the Kuwait Group was deposited.

\subsection{Hydrogeological setting}

The aquifers in Kuwait discussed in this study occur in the Dammam Formation and the Kuwait Group. Their lithological characteristics and depth are functions of geological sedimentation, deformation and erosion. Thus, the previous studies of the lithology, stratigraphy, structure, and regional geology of the area are essential to understanding the hydrogeology of AQULA. Moreover, salinity distribution, water types, water genesis and the condition of saturation with respect to most common minerals of the aquifers was studied. On the other hand, the hydrological conditions include the occurrence of a thick net of Gardening-irrigation system and presence of huge surface water bodies; e.g. AlQairawan lake. Besides that the Quaternary aquifer is poor in hydraulic properties where the porosity ranges from $5 \%$ to $20 \%$ (GII, 2010) while the transmissivity, hydraulic conductivity and storativity values were estimated by reanalyzing the available raw data of pumping test recorded by (GII, 2010) applying Jacob's straight line method (Cooper and Jacob, 1946) (Fig. 5 and Table 1). It ranged from 17 to $71 \mathrm{~m} /$ day. The highest estimated transmissivity value reaches $1998 \mathrm{~m} 2 / \mathrm{d}$ while the storativity reaches 0.00018 . The groundwater rise reaches $0.8 \mathrm{~m} /$ year. Moreover, the soil water depths vary from few centimeters below ground surface to $5.5 \mathrm{~m}$ and the groundwater moves generally from the southwest to the northeast towards the Arabian Gulf.
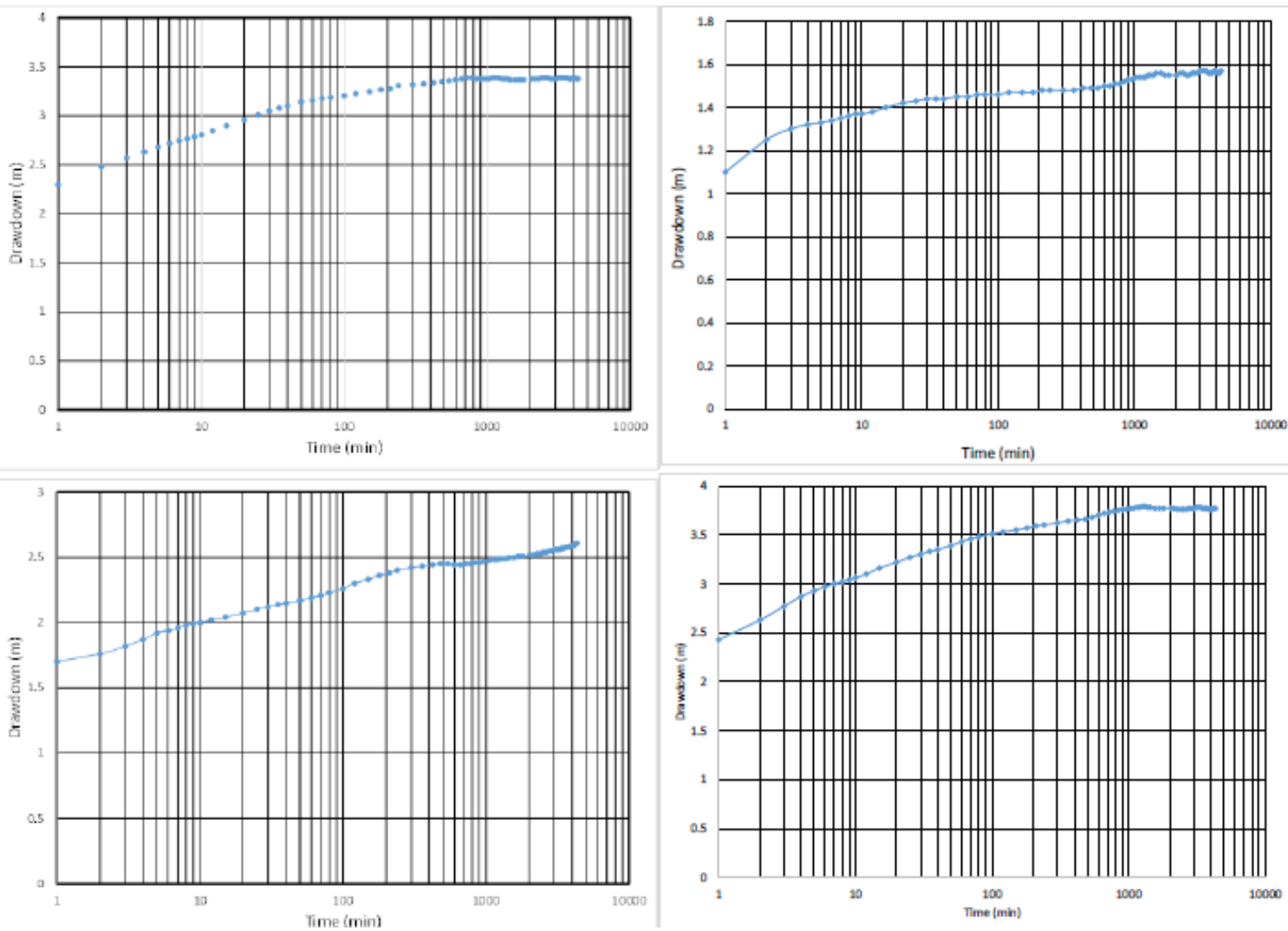

Fig. (5): Field data curves for observation wells JB-A JB-B JB-C, and JB-D.

Table 1. Hydraulic parameters of Kuwait Group aquifer at AQULA

\begin{tabular}{|c|c|c|c|c|c|c|}
\hline Location & $\mathbf{X}(\mathbf{U T M})$ & $\mathbf{Y}(\mathbf{U T M})$ & $\left.\mathbf{Q} \mathbf{( m}^{3} / \mathbf{d}\right)$ & $\left.\mathbf{T} \mathbf{( m}^{2} / \mathbf{d}\right)$ & $\mathbf{K}(\mathbf{m} / \mathbf{d})$ & Ss \\
\hline JB-A & 769,617 & $3,247,120$ & 916.47 & 987.56 & 35.27 & $1.8 \times 10^{-4}$ \\
\hline JB-B & 768,828 & $3,247,669$ & 916.47 & 466.18 & 16.64 & $1.8 \times 10^{-4}$ \\
\hline JB-C & 770,069 & $3,248,464$ & 654.62 & 1997.9 & 71.35 & $1.8 \times 10^{-4}$ \\
\hline JB-D & 770,016 & $3,248,400$ & 916.47 & 645.48 & 23.05 & $1.8 \times 10^{-4}$ \\
\hline JB-E & 767695 & 3250053 & 589.16 & 263 & 17 & $1.8 \times 10^{-4}$ \\
\hline
\end{tabular}




\section{MATERIAL AND METHODS}

The materials used in this paper were collected through carrying out four field trips in AQULA during the period 2015-16. A network of five well distributed observation wells penetrating the Quaternary aquifer in AQULA was chosen for periodic recording of soil water level during the year 2015. Installation of three Micro Divers inside three observation wells required for soil water pressure periodic monitoring beside one Baro Diver for recording the Barometric pressure were done during these field trips. The periodic monitoring of the soil water level was carried out automatically every 5 minutes. In the end of the time record interval the records were downloaded by Diver-Office 2012.1 software program (Fig. 6).
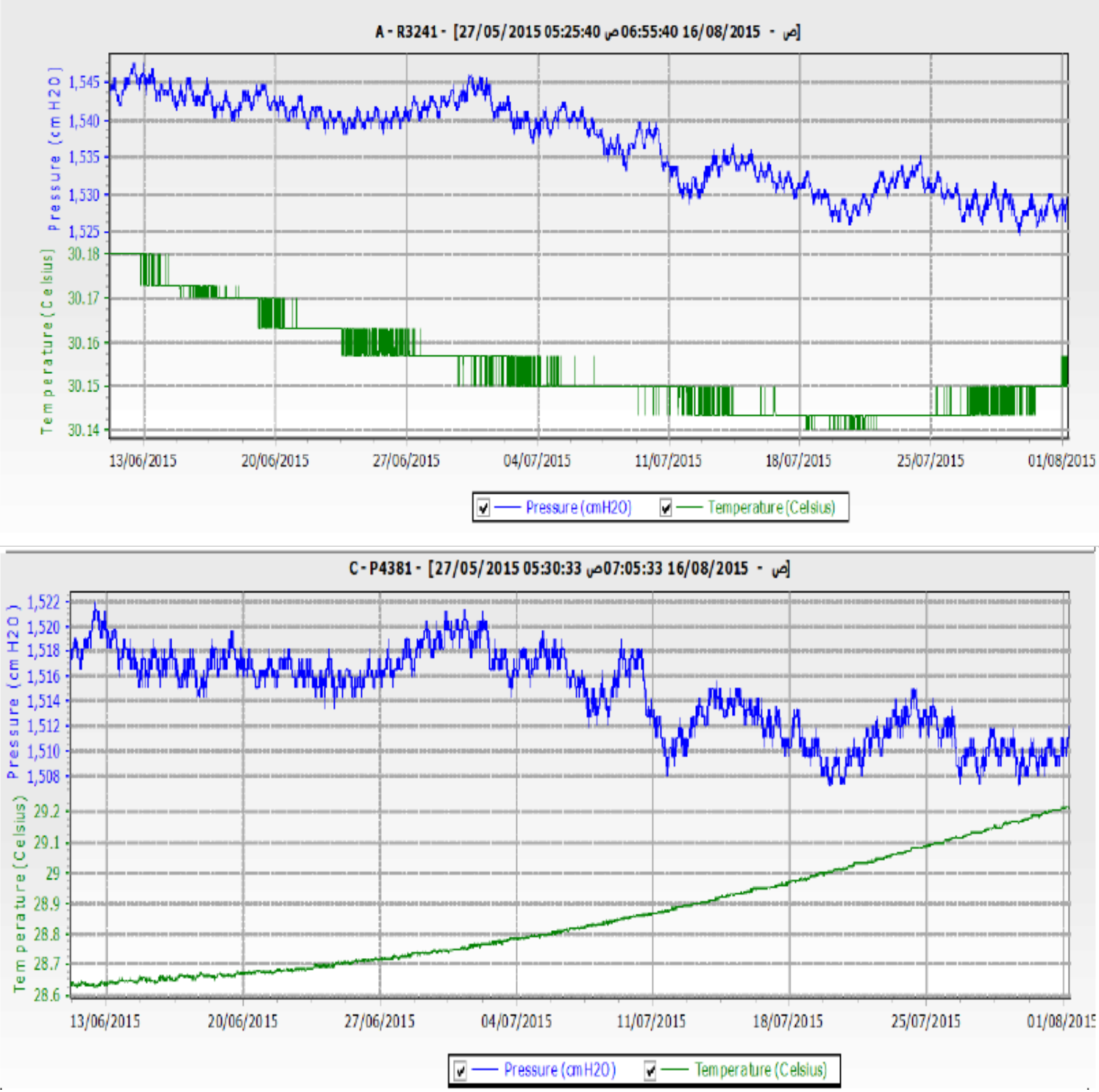

Fig. 6: The recorded groundwater fluctuation in piezometer A (upper) and piezometer $\mathrm{C}$ (lower) in AQULA

To calculate the water level in relation to a vertical reference datum using the Diver and BaroDiver's measurements, Figure (7) represents a typical example of a monitoring well in which a Diver has been installed. In this case, the height of the water level (WL) in relation to the vertical reference datum is measured. If the water level is situated above the reference datum it has a positive value and a negative value if it is situated below the reference datum.
The top of casing (TOC) is measured in relation to the vertical reference datum and is denoted in the diagram below as TOC $\mathrm{cm}$. The Diver is suspended with a cable with a length equal to $\mathrm{CL} \mathrm{cm}$. The Baro-Diver measures the atmospheric pressure (Pbaro) and the Diver measures the pressure exerted by the water column (WC) and the atmospheric pressure (PDiver). The water level (WL) in relation to the vertical reference datum can be calculated as follows: 


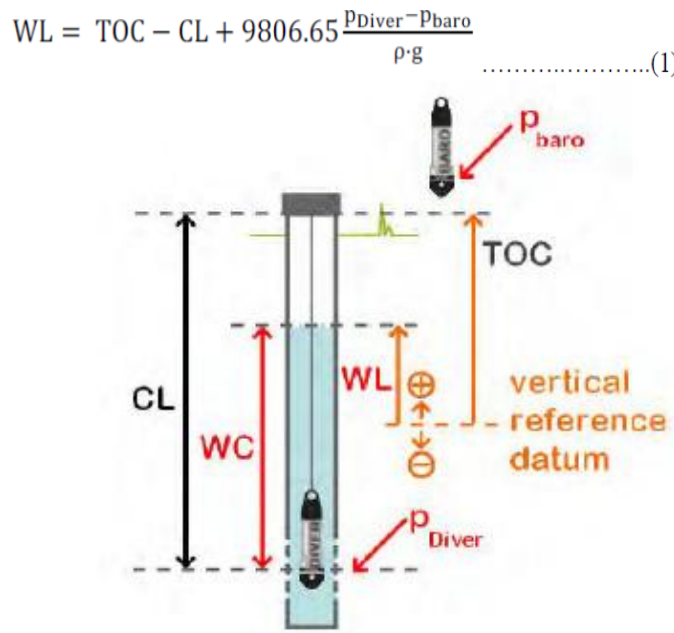

Fig. 7: Schematic diagram for water level calculation from Diver data

$\frac{\partial}{\partial x}\left(K_{x x} \frac{\partial h}{\partial x}\right)+\frac{\partial}{\partial y}\left(K_{y y} \frac{\partial h}{\partial y}\right)+\frac{\partial}{\partial z}\left(K_{z z} \frac{\partial h}{\partial z}\right)-W=S_{S} \frac{\partial h}{\partial t} \ldots \ldots \ldots \ldots \ldots . . .(2)$

In addition, the methodological approach used in this paper is based on the mathematical modeling techniques. Characteristics of the water logging problem in AQULA and its spatial and temporal variation, as well as its future behavior, were thoroughly investigated by means of numerical code (Visual MODFLOW, McDonald and Harbaugh1988). Visual MODFLOW (v.3) was applied to calibrate the physical parameters for the flow mechanism, and the initial conditions for flow were evaluated accordingly. The model describes groundwater flow under non-equilibrium conditions in a heterogeneous and anisotropic medium according to the following equation (Bear, 1979 and Bear \& Verruijt 1987):

Where Kxx, Kyy, Kzz are values of hydraulic conductivity along the $\mathrm{x}, \mathrm{y}$ and $\mathrm{z}$ coordinate axes $\left(\mathrm{LT}^{-1}\right)$; $\mathrm{h}$ is the piezometric head $(\mathrm{L})$; $\mathrm{W}$ is a volumetric flux per unit volume and represents source and/or sinks of water (T-1); Ss is the specific storage of the porous material $\left(\mathrm{L}^{-1}\right)$ and $\mathrm{t}$ is time $(\mathrm{T})$.

\section{Construction of the groundwater flow model}

The conceptual model of AQULA was based on the geology of the AQULA which was comprised Quaternary Kuwait Group sediments. The hydrogeologic system was concerned one aquifer with one complex layer that is composed mainly of very fine to coarse sand with $18 \mathrm{~m}$ thickness (Dibdibba Formation). Thin siltyclay layer of $3 \mathrm{~m}$ and sometimes sandy clay covers the water bearing Formation all over the AQULA while the bottom layer of this aquifer consists of clay and shale with $3 \mathrm{~m}$ thickness. This Quaternary groundwater aquifer occurs under the confining and semi-confining conditions and is characterized by lateral and vertical facies changes. The groundwater flows generally from the south and southwest to the north and northeast. The main recharging source is the seepage from the surface water of irrigated gardens while the main discharging source is the draining to the Arabian Gulf.

The simulation procedure was started by dividing the AQULA domain into a suitable grid pattern of 6300 cells (60 rows and 105 columns). The top and the bottom of the aquifer layer and the boundary conditions were assigned to this grid (Fig.8). The model domain with flow boundary conditions was chosen to cover an area of $278 \mathrm{~km}^{2}$. The modeled AQULA is surrounded by Generalflow boundary (pre-scribed head) from south and southeast in which the general groundwater head of 55 masl is present (Fig.8). This area is considered as groundwater recharge area. In the other side, the constant head boundary is obvious in the northern boundary of the AQULA due to the fact that the previous mentioned Arabian Gulf in the northern part of the studied area is very large and water head in it is relatively constant all over the year (Fig.8). Moreover, model geometry includes top and bottom of the aquifer layer. The top aquifer layer is extracted from DEM file (90x90m) of the AQULA while the bottom layer is generated by subtracting the aquifer thickness (18m) from the top aquifer layer data. The groundwater system is built by assigning the horizontal hydraulic conductivity ( $\mathrm{m} /$ day) and the Transmissivity values $\left(\mathrm{m}^{2} /\right.$ day) (Table 1) beside the initial hydraulic heads (m) (Fig.9) to the model grid by the previously mentioned method.

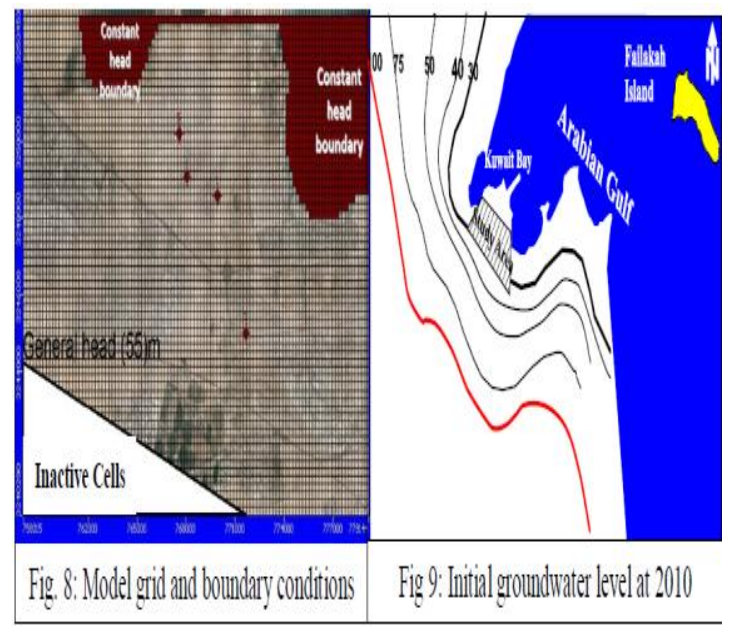


After the complete entering of the data required for building the model, it is allowed to run. If there is a convergence, an input data error is present which should be repaired time after time until the running process goes successfully.

\section{Model calibration}

Calibration is an essential step that makes simulated heads, match the actual measurement values with an acceptable range of error. Trial-anderror method is used in calibrating the Quaternary aquifer model of AQULA due to the great variations in $\mathrm{K}$-values and $\mathrm{T}$-values. Three piezometers' data are used to check the relation between the calculated and observed heads. After many times of changing the $\mathrm{k}$ values, the variance between the observed and calculated heads in case of steady state calibration was minimized and the normalized root mean squares (RMS) was decreased from $25.5 \%$ to $5.51 \%$ while it was decreased from $28.61 \%$ to $6.16 \%$ in case of unsteady state calibration by changing the Ss values (Fig. 10). The model was calibrated in steady state based on the soil water level in year 2010 (Fig.9) and in transient state according to the groundwater levels recorded by the Divers at 2015 . Subsequently, good agreement between observed and calculated water levels had been reached.
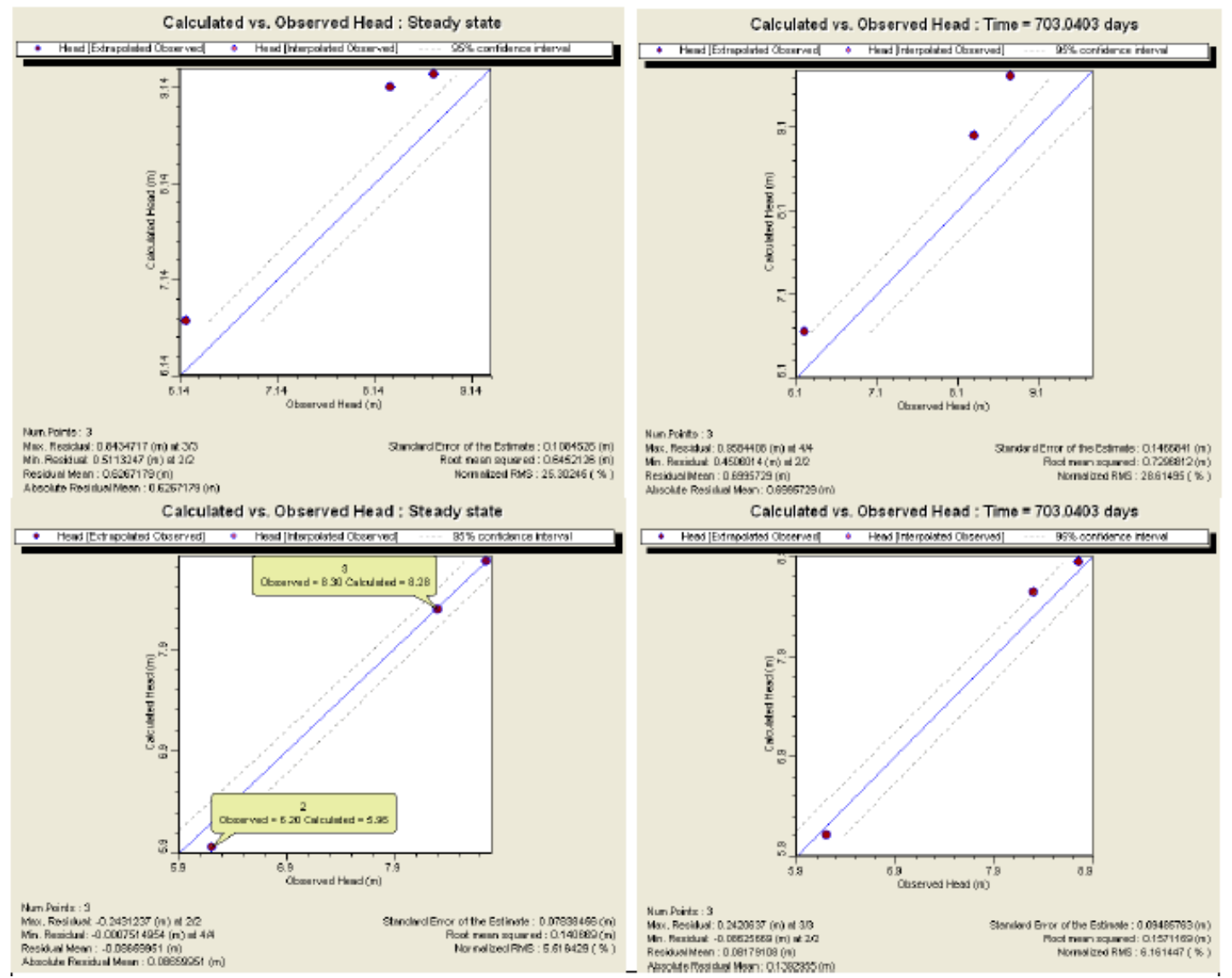

Fig. 10: Steady (left) and unsteady (right) state calibration results of the modeled area

\section{Testing scenarios}

After completing the stage of calibration, the output of the first round was used to replace the initial condition with the condition of studying the best scenario of water logging control. Among the methods of water logging control, three testing scenarios were chosen (Wall sheet scenario with three proposed cases, Dewatering scenario with two cases and Open Drain scenario with two cases). The first proposed case in Wall sheet scenario lies in the north of the logged area with depth of $9 \mathrm{~m}$ and length of $5 \mathrm{~km}$ while the second proposed case surrounds a lake in the south of the logged area and the third one lies in the south of the logged area. Otherwise, the first proposed case of dewatering scenario lies in the north of the logged area and supposes 20 dewatering wells with discharge rate of $2400 \mathrm{~m}^{3} /$ day/well while the second one lies in the middle of the logged area with discharge of $1500 \mathrm{~m}^{3 /}$ day/well. In addition, the first location of the proposed Drain based on the third scenario incorporates the southern part of AQULA while the second proposed location of Open Drain is due NE. 


\section{RESULTS AND DISCUSSION}

According to the groundwater level measurements (Table 2) the groundwater levels raised from 5.3 masl in Pizometer No. JB-B to 6 masl and from 5.8 masl in Pizometer No. JB-A to 6.2 masl with an increase of $0.7 \mathrm{~m} / \mathrm{year}$ and 0.4 $\mathrm{m} /$ year respectively. Moreover, the water table map at 2010 (Fig. 9) shows the curvature of contour lines relative to the directions of the irrigation network which indicates that the irrigated-
Gardening network acts as influent streams (recharge areas) in both southern and eastern boundaries, while it operates as effluent streams (discharging areas) in the northern part. Moreover, there is a remarkable rise in groundwater levels in the middle and western parts of the flat areas indicated by the concentric contour lines. This local rise may result either from the downward seepage from the irrigation water or the upward leakage from underlying aquifers (fractured limestone).

Table 2: Records of groundwater levels in AQULA during the interval 2015-2016

\begin{tabular}{|c|c|c|c|}
\hline \multicolumn{4}{|c|}{ Water Level above sea level in meter at AQULA (2015-2016) } \\
\hline Pizometer No. & May 2015 & August 2015 & April 2016 \\
\hline JB-A & 5.8 & 6 & 6.2 \\
\hline JB-B & 5.3 & 5.8 & 6 \\
\hline JB-C & 5.5 & 6 & 6.3 \\
\hline
\end{tabular}

In addition, the results of simulation model show based on the first scenario which proposed wall sheet barrier with thickness $15 \mathrm{~cm}$ and depth $11 \mathrm{~m}$ below ground surface to change groundwater direction far from waterlogged area caused water table decline of $2.2 \mathrm{~m}$ (Fig. 11).
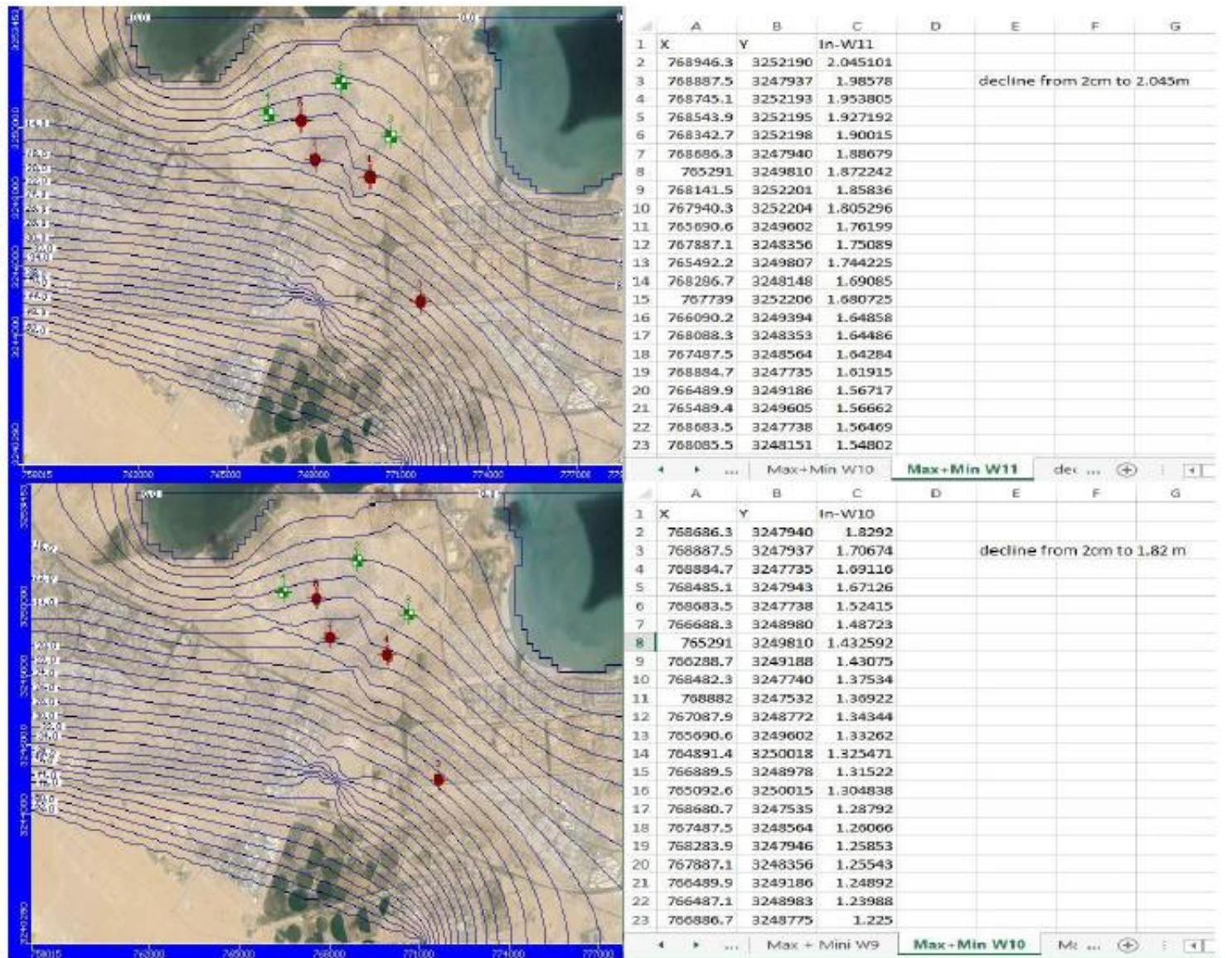

Fig 11: Predicted ground water contour maps applying wall sheet scenario with $11 \mathrm{~m}$ depth (upper) and 10m depth (lower) of AQULA 
The results of the second scenario for simulation of water logging mitigation was proposing 20 pumping wells with discharge capacity of $100 \mathrm{~m} 3 / \mathrm{hr}$ distributed around waterlogged area. The working period for pumping well system was one year. The maximum drawdown resulted from this scenario was $2.35 \mathrm{~m}$ and the minimum drawdown was $1.68 \mathrm{~m}$ (Fig. 12). Otherwise, the results from the third scenario (surface drain perpendicular to groundwater direction to lower groundwater level) exhibits maximum drawdown of $2.72 \mathrm{~m}$ and minimum drawdown of $1.62 \mathrm{~m}$ (Fig. 13).
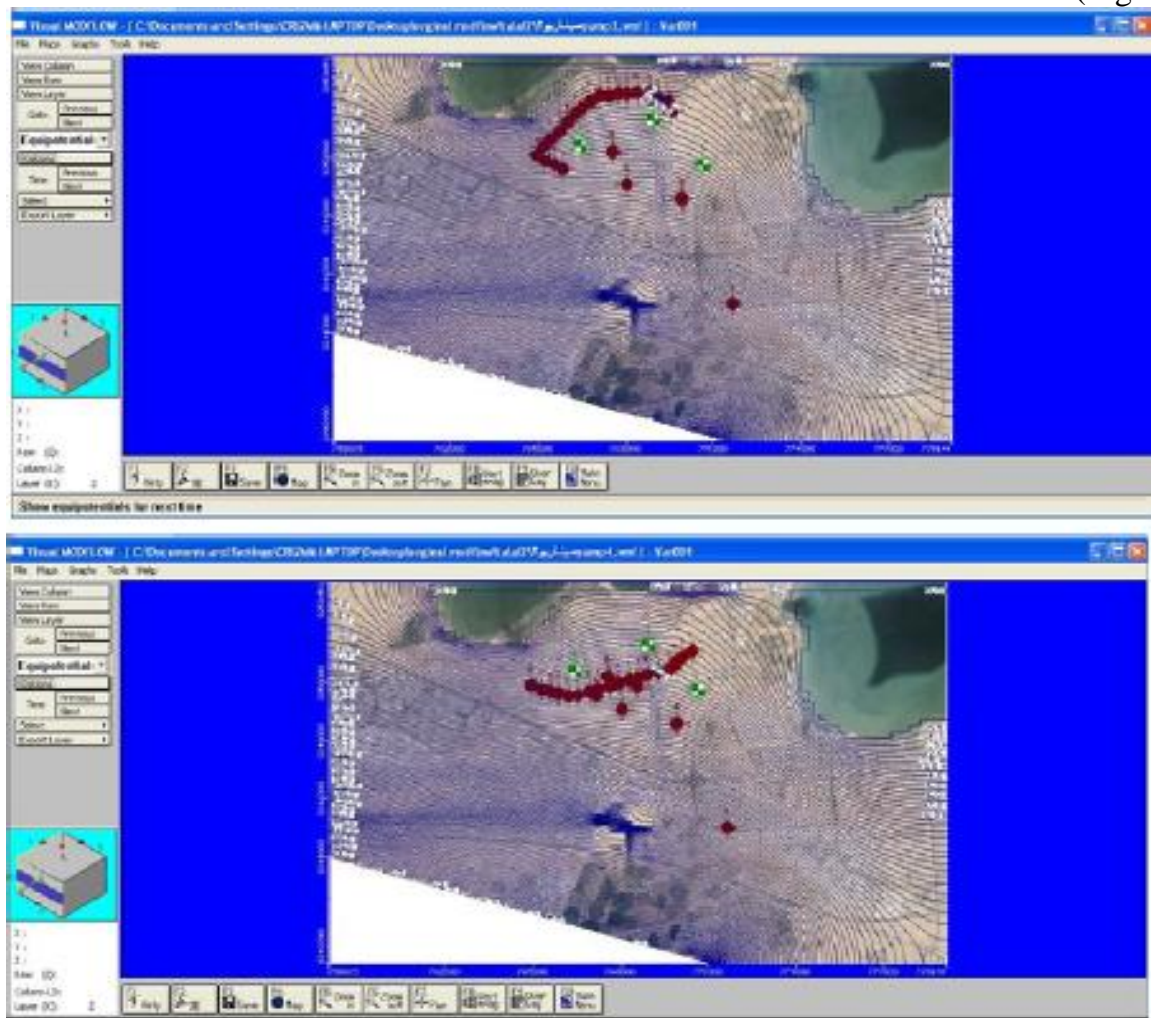

Fig 11: Groundwater level contour maps in case of dewatering system scenario in the upper side (upper map) and in the lower side (lower map) of AQULA.

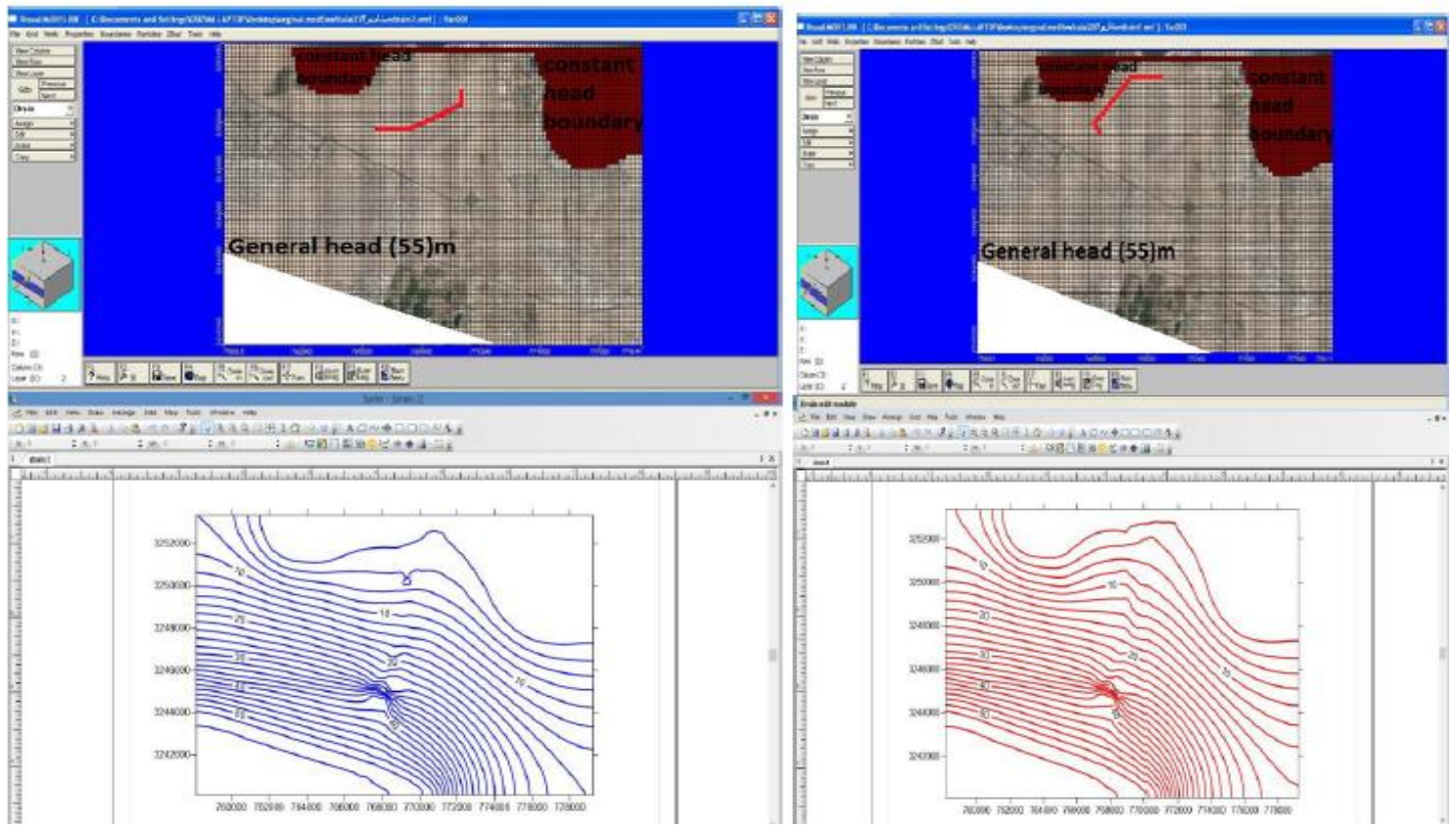

Fig 13: Ground water level contour maps applying open drain scenario in the southern part (left) and in the northern part (right) of AQULA 
In the other side, to study the economics of the different proposed solutions of water logging problem required for urbanization development of AQULA, cost benefit ratio of every scenario was estimated. The results of these estimations were tabulated in (Table 3) which reflects that the best solution of the waterlogging problem in AQULA was the Open drain scenario since its cost was the smallest one (146250 KD).

Table 3: The estimated costs of the different proposed scenarios of AQULA

\begin{tabular}{|c|c|c|c|}
\hline & wall sheet scenario & Dewatering scenario & Drain scenario \\
\hline cost & $\begin{array}{l}1 \mathrm{~m} 3=24 \mathrm{KD} \\
\text { We need } 5 \mathrm{~km} \text { to solve the problem. } \\
\text { Depth of wall } 10 \mathrm{~m} \\
5 \% \text { Labor building }\end{array}$ & $\begin{array}{l}\text { Excavate } 30 \mathrm{~m}=6000 \mathrm{KD} \\
\text { Pumping machine } 2000 \mathrm{KD} \\
\text { We need } 20 \text { wels }\end{array}$ & $\begin{array}{l}\text { Excovate Im=0.800 KD } \\
\text { We need } 5 \mathrm{~km} \\
\text { Depth } 3 \mathrm{~m} \\
\text { Cladding along the } \\
\text { canal }=5000^{*} 3^{*} 0.1^{*} 24=36000 \\
\text { KD }\end{array}$ \\
\hline Total of cost & $\begin{array}{c}24^{4} 5000^{*} 10^{*} 0.15= \\
180000 \times 0+9000 \times 0= \\
189000 K D\end{array}$ & $\begin{array}{l}8000^{*} 20= \\
160000 \times 0\end{array}$ & 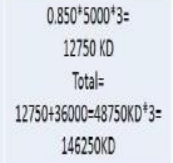 \\
\hline
\end{tabular}

\section{CONCLUSION AND} RECOMMENDATIONS

From this study it is concluded that the water logging problem is critical problem and threatens the urbanization development in the study area. Also, the flood irrigation of the cultivated lands and gardens is the essential reason for water logging problem. The obtained results from numerical simulation of the water logging problem reflect the bad needy of applying the most effective scenario, i.e., Open drain system.

According to the results of this study, there are many considerations to be take in the future as guide for similar studies, these consideration are:

1. Study the optimum management of soil water resources by studying the optimum abstraction from the aquifers.

2. Study the effect of salty lakes at the quality of groundwater in AQULA.

3. Changing the irrigation system from flood irrigation to modern irrigation system like drip irrigation.

4. The establishing of open drain system is essential for mitigate water logging problem in AQULA.

\section{REFERENCES}

[1] Al-Sarawi, M., (1982). The origin of Jal Az-Zor escarpment, Kuwait. Journal of the University of Kuwait (Science) 9: 151162.

[2] Al-Sulaimi, J.S. (1988). Calcrete and nearsurface geology of Kuwait City and suburbs, Kuwait, Arabian Gulf. Sedimentary Geology 54: 311 - 345.

[3] Al-Sulaimi, J.S. and Pitty, A.F. (1995). Original depositional model of wadi AlBatin and its associated alluvial fan, Saudi Arabia and Kuwait. Sedimentary Geology 97: 203 - 229.

[4] Al-Sulaimi, J. and Mukhopadhyay, A. (2000). An overview of the surface and near-surface geology, geomorphology and natural resources of Kuwait. Earth Science Reviews, v. 50, p. 227-267.

[5] Al-Sulaimi, J.S. and Al-Ruwaih, F.M., (2004). Geological, Structural and Geochemical Aspects of the Main Aquifer Systems in Kuwait. Kuwait J. Sci. Eng. 31(1) pp. 13-174, 2004.

[6] Amer, A, Barrat, J.M., Mukhopadhyay, A., Al-Sulaimi, J. \& Asem, A. (1989). Assessment of groundwater resources in Kuwait using remote sensing technology. Kuwait Institute for Scientific Research, Vol. 1, Report No. KISR 3197, Kuwait.

[7] Attia, F. (1989). Drainage problems in the Nile valley resulting from land reclamation. Irrigation and Drainage System, 3, 153-167.

[8] Bear, J. (1979). Hydraulics of Groundwater. McGraw-Hill, New York.

[9] Bear, J. and Verruijt, A. (1987). Modeling Groundwater Flow and Pollution. D. Reidel Publishing Company, Dordrecht, Holland. 414 pp.

[10] Burdon, D. J. and Al-Sharhan, A., (1968). The problem of palaeo- karstic Dammam Limestone aquifer in Kuwait. Journal of Hydrology, v. 6, pp. 358-404.

[11] Clarke, H.W.M. (1988). Stratigraphy and rock unit nomenclature in the oil producing area of interior Oman. Journal of Petroleum Geology, II (1): 5 - 60.

[12] Cooper, H.H. and C.E. Jacob, (1946). A generalized graphical method for evaluating formation constants and summarizing well field history, Am. Geophys. Union Trans., vol. 27, pp. 526534.

[13] El-Baz, F. and Al-Sarawi, M., (1996). Kuwait as an alluvial fan of a Paleo-river. Zeitschrift fur Geomorphologie NF 103: 49- 59. 
[14] El-Baz, F. and Al-Sarawi, M., (2000). Atlas of Kuwait from Satellite Images (Eng. \& Arab.). Kuwait Foundation for Advancement of Sciences, Grantz, Germany (Publisher). p. 145.

[15] El-Hefnawy, Gad, M. I., El-sheikh, A. E., Abdel Baki, A. A., M. A., and Abu ElFotouh, M. (2006): "Numerical simulation of the groundwater rise control in ElFayoum Depression, Western Desert, Egypt". 5th Int. Eng. Conf., Sharm ElSheikh, 12 Jan. 2006. pp 320-333.

[16] El-Nimr, A., (1991). Riyadh fights Rising Groundwater Problems, Water and Waste Water, Vol. 6, Issue 3, June 1991.

[17] El-Nimr, A., (1994). Management and Protection of Environment in Arriyadh Central Area, Tech. Report, Dec. 1994.

[18] El-Nimr (1995). Impacts of Rising Groundwater on Riyadh City Infrastructure and Buildings, Conf. Urban Habitat: The Environment of Tomorrow, Delft, Netherlands, Feb.1995.

[19] El-Rayes, A. E. and Geriesh, M. H.(2002). Reasons of waterlogging around serabium waste water treatment plant, Ismailia, Egypt. Third international conference for groundwater level control, pp.124-136.

[20] El Sheikh AE, El Osta MM and El Sabri MA, (2013). Study of the Phenomenon of Groundwater Levels Rise in South El Qantara Shark Area, Ismailia, Egypt. J Hydrogeol Hydrol Eng 2013, 2:2.

[21] Fuchs, W., Gattinger, T.E. \& Hozer, H.F. (1968). Explanatory text to the synoptic geological map of Kuwait. Vienna Geological Survey, Austria, 87 P.

[22] GAD, M.I.M. (2004). A Trial for Mitigation of Water Logging Problem in New Reclaimed Areas in the Desert Fringes of Beni-suef and El-Minya Governorates, Egypt. Mansoura Eng. Journal - Mansoura University, 29 (2), pages $33-52$.

[23] Garcia, L. A., Manguerra, H. B., and Gates, T. K. (1995). Irrigation-drainage design and management model: Development. J. Irrigation and Drainage Engineering, ASCE, 121(1), 71-82.

[24] Gates, T. K., and Grismer, M. E. (1989). Irrigation and drainage strategies in salinity-affected regions. J. Irrigation and Drainage Engineering, ASCE, 115(2), 255-284.

[25] Gates, T. K., Wets, W. J-B, and Grismer, M. E. (1989). Stochastic approximation applied to optimal irrigation anddrainage planning. J. Irrigation and Drainage Engineering, ASCE, 115(3), 488-502.

[26] Ghassemi, F., Jakeman, A. J., and Nix, H. A. (1995). Salinisation of land and water resources: human causes, extent,management and case studies. CAB International, Oxford, United Kingdom.

[27] Grismer, M. E., and Gates, T. K. (1991). Hydrologic aspects of saline water table management in regional shallowaquifers. Chapter 4 in Dinar, A., and Zilberman, D., eds. The economics and management of water and drainage inagriculture, Kluwer Academic Pub., Boston, Mass., pp. 51-70.

[28] Gulf Inspection International Company (GII, 2010). Technical report on drilling and construction of one drainage and monitoring well for Jaber Al-Ahmed- "W" 300/132/11Kv Substation.

[29] Hunting Geology and Geophysics (HGG) (1981). Photographical survey of the State of Kuwait. Submitted to the Kuwait Oil Company, Kuwait.

[30] Kaiser M F K, Rayes A, Geriesh B (2013). GIS Data Integration to manage waterlogging problem on the eastern Nile delta of Egypt. Geology Department, Suez Canal University, Egypt, International Journal of Geosciences, June 2013.

[31] Kovda, V. A. (1983). Loss of productive land due to silini7ztion. Ambio, 12(2), 9193. National Research Council. (1989). Irrigation induced water quality problems: What can be learned from the SanJoaquin Valley experience. National Academy Press, Washington, D. C.

[32] McDonald, M. G. and Harbaugh, A. W. (1988): MODFLOW, A modular three dimensional finite difference groundwater flow model. U. S. Geological Survey, Open-file report, pp. 83-875.

[33] Milton, D., (1967). Geology of the Arabian Peninsula, Kuwait. United States Geological Survey Professional Paper 560-F: 7 p.

[34] Mukhopadhyay, A. Al-Sulaimi, J., AlAwadi, E. and Al-Ruwaih, F., (1996). An overview of the Tertiary geology and hydrogeology of the northern part of the Arabian Gulf region with special reference to Kuwait. Volume 40, Issues 3-4, June 1996, Pages 259-295.

[35] Omar, S. A., Al-Yacoubi, A. and Senay, Y., (1981). Geology and groundwater hydrology of the State of Kuwait. Journal of the Gulf and Arabian Peninsula Studies (Kuwait Univ.). v. 1, pp. 5-67.Safar, M. I. 1985. Dust and dust storms in Kuwait. 
Civil Aviation Meteorological Dept., Kuwait.

[36] Owen, R. and Nasr, S., (1958). Stratigraphy of Kuwait-Basra. In: Weeks, L.G. (Ed.). Habitat of Oil: a Symposium. Pp. 1252-1278. American Association of Petroleum Geologists, Tulsa, OK, USA.

[37] Roy I. R., and Dhali, M. K., (2016). Seasonal Water logging Problem In A Mega City: A Study of Kolkata,. Journal of Research in Humanities and Social Science Volume 4 Issue 4(2016) pp:0109.

[38] Saafan, T. A. El-Sheikh, A. E. and Gad, M. I., (2009). Numerical simulation of the proper dewatering system as a tool of the groundwater rise control in El Fayoum depression-Egypt.

[39] Safar, M. I. (1985). Dust and dust storms in Kuwait. Civil Aviation Meteorological Dept., Kuwait.
[40] Sakr, S., Gad, M. I. M. and Millette, J. (2002). Mitigation options for water logging problems in closed basins: A case study from Siwa Oasis, Egypt. Proceedings of The 3rd International Conference of Groundwater Level Control Inside Urbanized Areas, Fac. of Eng., Mansoura Univ. pp 224-236 .

[41] Tanji, K. K., ed. (1990). Agricultural salinity assessment and management. ASCE Manuals and Reports onEngineering Practice No. 71, American Society of Civil Engineers, New York, N.

[42] Umali, D. L. (1993). Irrigation-induced salinity: a growing problem for development and the environment. World. Bank Technical Paper Number 215, The World Bank, Washington, D. C 